УДК 342.9

DOI https://doi.org/10.32838/TNU-2707-0581/2020.5/16

Чуб А.В.

Запорізький національний університет

\title{
СУБ'ЄКТИВНІ ПУБЛІЧНІ ПРАВА ПРИВАТНОЇ ОСОБИ ЯК ІНСТИТУТ АДМІНІСТРАТИВНОГО ПРАВА
}

У науковій статті здійснено характеристику теорії суб'єктивних публічних прав приватної особи в умовах сучасного розвитку науки адміністративного права. Метою даного дослідження є визначення сутності суб'єктивних публічних прав приватної особи як інституту адміністративного права. Визначено, що у взаємних відносинах між суб'єктами права та адміністративними органами автор виділяе три типові ситуащії, коли иі відносини відбуваються, та засади для їх виникнення: за умови наявності юридичного інтересу - якщо суб'єкт має кваліфікований юридичний інтерес, щодо якого орган адміністраџї̈ зобов'язаний виявити його законність і врахувати його, якщо це можливо (а якщо ні, то повинен виправдати відмову); за умови наявності фактичного інтересу - якщо суб'єкт господарювання у нинішній чи майбутній ситуації отримає пряму користь у результаті дій чи бездіяльності органу публічної влади; за умови наявності публічного суб' єктивного права - якщо суб'єкт звертається до адміністративного суду з позовом щодо вимоги від органу публічної влади конкретних дій (або утримання від певних дій), які він юридично зобов'язаний виконувати (утриматися) відповідно до свого призначення. Як висновок обтрунтовано, щя загальнотеоретичний підхід до визначення категорії «суб' єктивних публічних прав» будується на визнанні визначальними їх ознаками певних не правових, а психологічних феноменів: волі, інтересу, потенційної активності. Наголошено, щцо особливості соціокультурного розвитку вітчизняного адміністративного права зумовили певний занепад наукового інтересу до тематики суб'єктивних публічних прав; наслідком иъього є сьогоденна ситуація недостатнього дослідження иієї проблеми.

Ключові слова: історико-правова характеристика, суб'єктивні публічні права, приватна особа, становлення, адміністративний орган.

Постановка проблеми. Виправити ситуацію в бік паритету сторін публічно-правових відносин спроможний концепт суб'єктивних публічних прав приватної особи. У найбільш загальному розумінні саме суб'єктивні публічні права надають своєму носію право вимагати від суб'єкта публічної влади певної поведінки, тобто роблять тотожними у правовому аспекті позиції владних і невладних учасників публічно-правових відносин. Іншими словами, конструкція суб'єктивного публічного права надає приватній особі права, а органи публічної влади наділяє обов'язком реалізувати ці права чи сприяти їх реалізації. Зазначене спонукає адміністративістів до перегляду теоретико-методологічних підвалин адміністративно-правової науки. Саме тут актуалізується питання введення в наукове поле адміністративного права теорії суб'єктивних публічних прав як доктрини, протилежної державно-управлінській радянській концепції, такої, що здатна виконати роль парадигмального ядра для конструювання дійсно людиноцентристської моделі адміністра- тивного права в Україні. Протилежність цієї теорії методологічним засадам адміністративної науки СРСР неодноразово підкреслювалась у фаховій літературі. Наприклад, О.В. Винницький стверджує, що державно-управлінська орієнтація адміністративного права, наслідки якої у вигляді теоретико-методологічної кризи спостерігаються в науці сьогодні, не може співіснувати в одному полі 3 доктриною суб'єктивних публічних прав; ці концепції конкурують, між ними існує глибинний філософсько-правовий конфлікт [1]. Іншими словами, доктрина суб'єктивних публічних прав у цьому світлі виглядає як нове для вітчизняної адміністративно-правової науки теоретичне утворення. У зв'язку із цим необхідно приділити увагу розгляду історичних коренів та розвитку концептуальних розробок тематики суб'єктивних публічних прав, що, власне, й виступає головним науковим завданням цього підрозділу.

Стан наукової розробки проблеми. Варто виділити наукові розробки таких вчених, як В.Б. Авер'янов, Ю.П. Битяк, В.І. Васильєва, 
О.В. Гончарук, Б.М. Дронів, С.П. Погребняк, Р.В. Сивий, В.М. Селіванов, В.В. Галунько, Р.А. Калюжний, М.П. Кунцевич, Ю.О. Легеза, С.В. Савченко, О.М. Вінник, С.В. Курінний, В.К. Колпаков, Т.О. Коломоєць, А.Я. Курбатов, С.Т. Гончарук та ін. Однак у дослідженнях представників адміністративної науки відсутнім $є$ комплексне дослідження становлення та розвитку концепції суб'єктивних публічних прав. Метою даного дослідження $є$ здійснення характеристики концепції суб'єктивних публічних прав у сучасних умовах розвитку науки адміністративного права.

Виклад основного матеріалу. Слід зазначити, що у фаховій літературі зустрічаються різні думки стосовно історії юридичного поняття «суб’єктивні права»: деякі вчені вважають, що його засади були закладені ще в римському праві [2], інші пов'язують його родословну із працями гуманістів XVI століття, треті називають початком дослідження суб'єктивних прав епоху теоретичного панування школи природного права [3]. Розходяться думки дослідників і стосовно критеріїв розмежування окремих теорій суб'єктивного публічного права. Наприклад, В. Дурденевський стверджує необхідність використовувати для визначення суб'єктивних публічних прав метаюридичні критерії, на підставі чого виділяє такі концепції, в межах яких відбувалося трактування досліджуваного об'єкта: теорія волі, теорія інтересу, змішана теорія волі й інтересу, нормативна і психологічна теорії [4]. Зазначимо, що більшість науково-історичних реконструкцій теоpiї суб' єктивних прав спираються саме на таку позицію. Однак А. Михайлов, навпаки, говорить про малу гносеологічну цінність подібного розділення, адже юридичні конструкції пов'язані 3 філософськими вченнями досить поверхово, більшою мірою залежачи від практичної сторони правової дійсності; на його думку, слід було б продемонструвати специфіку розуміння суб'єктивних прав із позиції різних типів трактування самого права як юридичного феномена [3].

Важливо оговорити, що це «подальше становлення» відбувалося головним чином поза межами вітчизняної науки. Західноєвропейські правники-адміністративісти деякий час продовжували активно дискутувати з зазначеного приводу, намагаючись чіткіше окреслити юридичну природу та історико-культурну специфіку суб'єктивних прав; водночас українська адміністративно-правова наука в радянський період оголосила це вчення, як і інші важливі публічно-правові кон- цепції, конструкції та категорії, «застаріло буржуазним», винісши його тим самим за рамки дослідницької уваги. Притаманне радянській науці розуміння адміністративної діяльності виключно крізь призму управління людьми не сприяло уявленню індивіда як центральної фігури юридичної системи, відповідно, суб'єктивні права як інструмент його висунення в центр цієї системи також не осмислювались і не аналізувались [1]. Сьогодні в європейській правовій науці суб'єктивні публічні права нечасто виступають об'єктом досліджень; вони усталено розуміються як права приватних осіб в юридичних відносинах із державними органами (органами публічної влади), що захищаються в адміністративному суді й переважно виступають елементом практичної адміністративно-юстиційної діяльності.

Так, сучасна німецька доктрина до суб'єктивних публічних прав відносить усі права приватних осіб, що визнані правопорядком, незалежно від рівня та ієрархії правових норм. Адміністративно-судова практика Німеччини, за твердженням О.Б. Зеленцова, при цьому спирається на теорію «захисної норми» О. Бюллера. Згідно із цією теорією норма права може слугувати базою виникнення суб'єктивних публічних прав у тому разі, якщо вона виключає використання вільного розсуду адміністративних органів; якщо захищає інтереси окремої особи або групи осіб; якщо суб'єкти інтересів наділені можливістю вимагати від адміністративних органів певних дій або бездіяльності для реалізації цих інтересів [2]. Саме наявністю захисної норми поряд із наявністю інтересу особи в захисті їі порушеного суб'єктивного публічного права дією або бездіяльністю публічної влади традиційно характеризують допустимість адміністративного позову [5].

У німецькому адміністративно-правовому просторі категорія суб'єктивних публічних прав також тісно корелює 3 поняттям інтересу - публічного інтересу. При цьому публічний інтерес розглядається скоріше як природний інтерес особистості, що отримав «вірне трактування» й відповідне закріплення в нормативно-правових документах [6]. Тобто в такому сенсі правові норми, спрямовані на реалізацію публічного інтересу, водночас сприяють реалізації інтересу окремої особи. Цей постулат ілюструється тим, як теорія інтересу в німецькому адміністративному праві тісно співвідноситься 3 конструкцією суб'єктивного публічного права. Суть цієї конструкції полягає в гарантуванні дотримання прав, свобод та законних інтересів приватних осіб, набутті ними ста- 
тусу повноцінних та рівноправних учасників адміністративних правовідносин, отримуючи внаслідок цього можливість за власною ініціативою вступати у відносини із представниками публічної влади та вимагати від них відповідної поведінки [7]. Внаслідок цього кожна особа стає активним учасником адміністративних правовідносин, самостійним щодо органів публічної влади. Суб'єктивне публічне право виявляється в тому, що правова норма водночас спрямована на досягнення публічного інтересу й інтересу окремого індивіда. У результаті законодавством встановлюється відповідальність адміністрації стосовно громадянина, а тому гарантується можливість захисту інтересів [6].

Тобто нормативні підвалини суб'єктивного публічного права мають відповідати низці вимог, таких як: імперативність норми; сама норма, як i юридичний обов'язок публічних органів, що 3 неї випливає, мають водночас забезпечувати реалізацію публічного інтересу й захищати інтереси окремого індивіда як приватного суб'єкта [5]. Визнання публічного суб'єктивного права за приватною особою у правовій нормі, яка містить це право, не потребує чіткого формулювання цього права або визначення його як домагання; важливо лише, щоб зазначена норма відповідно до об'єктивної волі законодавця слугувала не тільки публічному інтересу, а й індивідуальному інтересу приватної особи [8, с. 112]. Слід також оговорити, що зазначене трактування публічних суб’єктивних прав як можливості індивіда захищати порушені власні інтереси створює деякі труднощі для судового захисту індивідом публічних інтересів і колективних прав; цей аспект сьогодні досить активно дискутується в німецькій адміністративістиці, становлячи виняток у здебільшого усталеній сфері теоретичного осмислення реалізації суб' єктивних публічних прав [5].

Дещо інакше виглядає ситуація у сфері адміністративно-правового теоретизування Польщі, де адміністративно-правова наука, як і в Україні, деякий час перебувала у стані занедбаності через належність держави до соціалістичного табору. У польських підручниках 3 адміністративного права сутність суб'єктивних публічних прав пояснюється в такий спосіб. Кожний орган публічної влади юридично зобов' язаний діяти відповідно до свого призначення. Громадянин має право вимагати від цього органу конкретних дій або утримання від певних дій, а у разі відмови - звернутися до адміністративного суду [9]. Польські дослідники вказують на дуалістичний характер суб'єктивних публічних прав. 3 одного боку, індивід, що має публічне суб'єктивне право, уповноважений самостійно визначати зобов'язання, яке автоматично покладається на представника публічної влади; 3 іншого, їх можна трактувати як певні інтереси, або юридичні конструкції, які створюють інтереси, юридично надані фізичній особі (громадянину), головною відмітною рисою яких є можливість примусового виконання, навіть якщо це тягне за собою обов'язковий характер певного типу поведінки органу публічної адміністрації [10].

Польськаправниця К. Томашевська стверджує, що головне призначення суб'єктивних публічних прав, що історично їм притаманне, - організація судового контролю за забезпеченням прав громадян. Саме ними користується кожен громадянин, щоб забезпечити власний захист та правову безпеку. Таким чином, публічне суб'єктивне право фізичної особи має як процесуальні, так і матеріальні аспекти, об'єктивуючись у позові - проти держави, проти публічної влади, проти всієї адміністративної діяльності. Зазначені права тісно пов'язані із законними інтересами; певною мірою, вважає дослідниця, навіть можна говорити, що суб'єктивні публічні права становлять категорію, яка поглинає явище інтересу і захищає його у спосіб, що на процедурному рівні тісно пов'язаний із правом подати скаргу. При цьому авторка стверджує про недостатній рівень дослідження суб'єктивних публічних прав у польській науці адміністративного права й недооціненість значення цього інституту в юридичній практиці [11, с. 117].

Аналогічний висновок роблять i сучасні науковці пострадянського простору, намагаючись заповнити наявні теоретичні та практичні прогалини. У цій справі їм доводиться спиратися передусім на озвучені нами вище класичні теорії розуміння суб'єктивних публічних прав, вироблені в межах німецької адміністративістики, адже на вітчизняних теренах наукові розробки із цієї тематики характеризуються коротким етапом зародження в дорадянський період, недовгим сплеском уваги в радянські часи й зараз переживають поступове повернення наукової зацікавленості після довгих років забуття. Серед дослідників дорадянської епохи, окрім уже цитованих, у цій роботі згадаємо В.М. Дурденевського, Б.О. Кістяківського, Г.Ф. Шершеневича, Л.І. Петражицького, М.М. Коркунова, І.О. Ільїна, П.І. Новгородцева тощо. Узагальнюючи їхній теоретичний внесок, I.M. Васев доходить висновку про пре- 
валювання психологічно-індивідуальної установки як методологічної засади розуміння публічних суб'єктивних прав у працях зазначених авторів. Такому підходу притаманні відмова від тези про примат об'єктивного права перед суб'єктивним, надання суб'єктивним правам пріоритетної позиції, виділення індивідуальних волі та інтересу як сутнісних характеристик досліджуваних прав [12]. Зовсім інші, позитивістські методологічні підвалини використовували радянські адміністративісти у своїх спробах визначити суб'єктивні публічні права та їхні місце і роль у адміністративноправових реаліях. Так, С.Н. Братусь у 1947 р. визначив суб'єктивні права як «міру можливої поведінки» [13, с. 183]; Н.Г. Александров у 1955 р. назвав суб'єктивними правами тріаду правомочностей володаря суб'єктивного права (можливість обирати власні дії; можливість вимагати поведінки, що забезпечила б реалізацію першої можливості, від інших осіб; можливість вдатися до сприяння державного апарату в разі необхідності) [1]. Головне теоретичне досягнення теоретиків права в радянські часи вбачається дослідниками в тому, що воля та інтерес, які в попередні часи розглядалися як визначальні ознаки суб'єктивного публічного права, перестали такими бути й розглядалися виключно як допоміжні, інструментальні чинники; зміст суб'єктивного права пояснювався як «міра можливої поведінки» в межах об'єктивного права. При цьому, за зауваженнями дослідників, суб'єктивному праву відводилася вторинна, інструментальна роль стосовно об'єктивного [12].

Таку, умовно кажучи, «теоретико-методологічну спадщину» отримали сучасні пострадянські представники адміністративно-правової науки у сфері дослідження суб'єктивних публічних прав.
Щиро кажучи, кількість теоретичних досліджень на цю тематику не можна вважати вичерпною або навіть достатньою. Так, серед українських дослідників можна назвати К.М. Васьківську, Т.О. Мацелик, О.М. Пасенюка, Д.М. Папу, О.Ю. Синявську тощо, в працях яких було досліджено цю проблематику. У теоретично-правовому полі пострадянських держав уваги заслуговують розробки I.М. Васева， О.Б. Зеленцова， Г.В. Мальцева, Е.В. Талапіної, Ю.О. Тихомірова, С.М. Хорунжого та ін. Огляд робот названих авторів дозволяє впевнено стверджувати наявність тенденції визначати суб'єктивні публічні права в дусі радянської традиції; як міру можливої (дозволеної) поведінки трактує їх О.Ю. Синявська [14]; як визнання можливості отримати певне суспільне благо, гарантоване нормою об'єктивного права, - О.М. Пасенюк [15]; як індивідуально-конкретну вольову, владну міру свободи поведінки суб'єкта права, яка надається з метою задоволення його інтересів та забезпечена відповідними обов'язками інших суб'єктів та гарантіями держави, - Т.О. Мацелик [16].

Висновок. Підбиваючи підсумки проведеного аналізу історії становлення концепту «суб' єктивне публічне право», можемо зробити такі загальні висновки. По-перше, науковий інтерес до цього феномена, як і його теоретична артикуляція, виникають наприкінці XIX століття в німецьких правників, роль яких у справі розвитку теорії суб'єктивного публічного права справедливо вважають головною; завдяки їхнім працям розуміння суб'єктивного публічного права як юридичного феномена тісно пов'язане 3 адміністративною юстицією. По-друге, особливості соціокультурного розвитку вітчизняного адміністративного права зумовили певний занепад наукового інтересу до тематики суб'єктивних публічних прав; наслідком цього $є$ сьогоденна ситуація недостатнього дослідження цієї проблеми.

\section{Список літератури:}

1. Винницкий А.В. Учение о субъективных публичных правах «государственно-управленческого подхода» в науке. Право и политика. 2018. № 12. С. 27-40.

2. Зеленцов А.Б. Субъективное публичное право : учеб. пособие. Москва : Российский университет дружбы народов, 2012. 148 с.

3. Михайлов А.М. Субъективное право: размышления теоретика. Право: блог. URL : https://blog.pravo. $\mathrm{ru} / \mathrm{blog} / 5906 . \mathrm{html}$.

4. Дурденевский В.Н. Субъективное право и его основное разделение. Правоведение. 1994. № 3. C. 78-95.

5. Гриценко Е.В., Хайнтцен М. Доступ к судебной защите в России и Германии. Вестник СанктПетербургского университета. Право. 2019. 10 (4).C.733-755.URL: https://doi.org/10.21638/spbu14.2019.409.

6. Шерстобоев О.Н. Теория интересов в административно-правовом измерении. Российский юридический журнал. 2014. № 3. С. 99-108. 
7. Мельник Р.С. Загальне адміністративне право : навч. посіб. Київ : Ваіте, 2014. 376 с.

8. Рихтер И., Шупперт Г.Ф. Судебная практика по административному праву. Москва : Юристь, $2000.604 \mathrm{c}$.

9. Koncepcja publicznych praw podmiotowych. Lexplay: doradztwo prawne. URL : https://lexplay.pl/artykul/ prawo administracyjne/koncepcja publicznych praw podmiotowych1.

10. Chaciński J. Prawa podmiotowe a ochrona dóbr osobistych. Lublin, 2004. $210 \mathrm{~s}$.

11. Tomashewska K. Znaczenie i zakres ochrony publicznych praw podmiotowych a ochrona interesu jednostki. Folia juridika Wratislaviensis. 2014. № 2. S. 113-134. S. 117.

12. Васев И.Н. Субъективное право как общетеоретическая категория: монография. Москва : Юрлитинформ, 2014. 189 с.

13. ИвановЭ.И.Понятие субъективногоправа. Марийскийюридическийвестник. 2011.Вып. 8.С.182-190. URL : https://cyberleninka.ru/article/n/ponyatie-subektivnogo-prava-1.

14. Синявська О.Ю. Суб’єктивні публічні права приватних осіб. Право і безпека. 2010. № 2(34). С. 52 -55.

15. Пасенюк О. До питання природи суб'єктивного публічного права. Право України. 2008. № 8. C. 58-63.

16. Мацелик Т.О. Суб'єктивне публічне право як юридичний феномен. Юридичний вісник. 2011. № 3(20). C. 67-71.

\section{Chub A.V. SUBJECTIVE PUBLIC RIGHTS OF A PRIVATE PERSON AS AN INSTITUTE OF ADMINISTRATIVE LAW}

The scientific article describes the theory of subjective public rights of an individual in the modern development of the science of administrative law. The purpose of this study is to determine the essence of the theory of subjective public rights of the individual in the modern development of the science of administrative law. It is determined that the mutual relations between subjects of law and administrative bodies, the author identifies three typical situations when these relations occur, and the principles for their occurrence: provided there is a legal interest - if the subject has a qualified legal interest in which the administrative body is obliged to identify its legality and take it into account, if possible (and if not, must justify the refusal); provided that there is a factual interest - if the business entity in the current or future situation will receive direct benefits as a result of actions or inaction of a public authority; subject to the existence of a public subjective right - if the subject applies to the administrative court with a claim for a requirement from a public authority of specific actions (or refrain from certain actions), which he is legally obliged to perform (withhold) in accordance with its purpose. As a conclusion, it is substantiated that the general theoretical approach to defining the category of "subjective public rights" is based on the recognition of their defining features of certain not legal but psychological phenomena: will, interest, potential activity. It is emphasized that the peculiarities of the socio-cultural development of domestic administrative law have led to a certain decline in scientific interest in the subject of subjective public rights; the consequence of this is the current situation of insufficient research of this problem.

Key words: historical and legal characteristics, subjective public rights, individual, formation, administrative body. 